\title{
Phytophthora Root and Collar Rot of Paulownia, a New Disease for Europe
}

\author{
Francesco Aloi $1,2,+$, Mario Riolo ${ }^{1,3,4,+}$, , Federico La Spada ${ }^{1}$, Gaetano Bentivenga ${ }^{5}\left(\mathbb{D}\right.$, Salvatore Moricca ${ }^{6}(\mathbb{D}$, \\ Elena Santilli ${ }^{4}$, Antonella Pane ${ }^{1}\left(\mathbb{D}\right.$, Roberto Faedda ${ }^{1, *(\mathbb{D})}$ and Santa Olga Cacciola ${ }^{1, *(\mathbb{D})}$ \\ 1 Department of Agriculture, Food and Environment, University of Catania, 95123 Catania, Italy; \\ francesco.aloi@unipa.it (F.A.); mario.riolo@unirc.it (M.R.); federico.laspada@unict.it (F.L.S.); \\ apane@unict.it (A.P.) \\ 2 Department of Agricultural, Food and Forest Sciences, University of Palermo, 90128 Palermo, Italy \\ 3 Department of Agriculture, University Mediterranea of Reggio Calabria, 89122 Reggio Calabria, Italy \\ 4 Council for Agricultural Research and Economics, Research Centre for Olive, Fruit and Citrus \\ Crops (CREA-OFA), 87036 Rende, Italy; elena.santilli@crea.gov.it \\ 5 Valagro S.p.A., Via Cagliari, 1, 66041 Atessa, Italy; gaetano.bentivenga@virgilio.it \\ 6 Department of Agricultural, Food, Environmental and Forestry Science and Technology, University of \\ Florence, 50144 Firenze, Italy; salvatore.moricca@unifi.it \\ * Correspondence: rfaedda@unict.it (R.F.); olga.cacciola@unict.it (S.O.C.) \\ + These authors have equally contributed to the study.
}

Citation: Aloi, F.; Riolo, M.; La Spada, F.; Bentivenga, G.; Moricca, S.; Santilli, E.; Pane, A.; Faedda, R.; Cacciola, S.O. Phytophthora Root and Collar Rot of Paulownia, a New Disease for Europe. Forests 2021, 12, 1664.

https://doi.org/10.3390/f12121664

Academic Editor: Rimvydas Vasaitis

Received: 26 October 2021

Accepted: 28 November 2021

Published: 30 November 2021

Publisher's Note: MDPI stays neutral with regard to jurisdictional claims in published maps and institutional affiliations.

Copyright: (c) 2021 by the authors. Licensee MDPI, Basel, Switzerland. This article is an open access article distributed under the terms and conditions of the Creative Commons Attribution (CC BY) license (https:// creativecommons.org/licenses/by/ $4.0 /)$.

\begin{abstract}
Paulownia species are fast growing trees native to China, which are being grown in managed plantings in several European countries for the production of wood and biomasses. In 2018, wilting, stunting, leaf yellowing, and collapse, as a consequence of root and crown rot, were observed in around $40 \%$ of trees of a 2-year-old planting of Paulownia elongata $\times$ P. fortunei in Calabria (Southern Italy). Two species of Phytophthora were consistently recovered from roots, basal stem bark, and rhizosphere soil of symptomatic trees and were identified as Ph. nicotianae and Ph. palmivora on the basis of both morphological characteristics and phylogenetic analysis of rDNA ITS sequences. Koch's postulates were fulfilled by reproducing the symptoms on potted paulownia saplings transplanted into infested soil or stem-inoculated by wounding. Both Phytophthora species were pathogenic and caused root rot and stem cankers. Even though P. palmivora was the only species recovered from roots of naturally infected plants, in pathogenicity tests through infested soil P. nicotianae was more virulent. This is the first report of Phytophthora root and crown rot of a Paulownia species in Europe. Strategies to prevent this emerging disease include the use of healthy nursery plants, choice of well-drained soils for new plantations, and proper irrigation management.
\end{abstract}

Keywords: princess tree; tree of life; Phytophthora nicotianae; Phytophthora palmivora; Phytophthora heterospora; DNA sequencing; phylogenetic analysis; Paulownia elongata $\times$ P. fortunei; biomass and timber; nursery plants; pathogenicity

\section{Introduction}

The genus Paulownia, formerly in the family Scrophulariaceae and now regarded as a member of the mono-generic and mono-phyletic family Paulowniaceae according to the Fourth Angiosperm Phylogeny Group (APG IV) classification system, encompasses deciduous hardwood tree species, very probably native to south-eastern China [1,2]. Paulownia species are among the most popular cultivated trees in China. The species of greatest commercial importance worldwide are P. tomentosa, P. elongata, P. fortunei, P. catalpifolia, and P. kawakamii. Paulownia tomentosa, which has a long life and is cold-tolerant, is the most widespread species. It behaves as a pioneer species and has been largely used to reclaim disturbed natural, urban, and industrial sites. It was naturalized in Japan and Korea and was the first species of this genus to be known in Europe, where it has been grown as an ornamental tree for over 150 years. In some areas of the U.S.A., where P. tomentosa was 
introduced in the 19th century, it has been naturalized and is considered invasive [3,4]. The invasiveness of $P$. tomentosa is due to the ability to propagate vegetatively by suckering and resprouting after cutting, as well as to an impressive reproductive potential. A single tree can produce around 20 million seeds, which are winged and can be dispersed by wind up to a distance of about $10 \mathrm{~km}$. Moreover, this Paulownia species with its vigorous growth and the shadowing of its large leaves competes with native vegetation and prevents its regeneration [5]. Differently from the U.S.A., in European countries where it has been naturalized, including Great Britain, Germany, France, Switzerland, Austria, Italy, and Spain, $P$. tomentosa is not yet regarded as a nature conservation issue [6]. However, this is controversial and has to be re-examined also in the light of climate change which could favor the spread of P. tomentosa beyond its present distribution [7]. In any case, it would be advisable to cautiously spread this alien plant species and prevent it from escaping from ornamental or commercial plantations to more natural habitats as happened in the U.S.A. Paulownia elongata and P. fortunei are more thermophilic, very fast-growing tree species, suitable for biomass and wood production in warmer areas of southern Europe, such as Italy and Spain. They seem less invasive than P. tomentosa [5]. Paulownia catalpifolia is not so widely cultivated as other species as it is relatively slow-growing, but produces wood of better quality. Paulownia kawakamii, which is considered an endangered plant species in nature since it is almost extinct in the wild, is cultivated for its high quality wood. Paulownias are propagated by seeds, root cuttings, or micro-propagation and are known by several common names, such as princess tree, empress tree, foxglove tree, tree of life, and karri (in English) or kiri (in Japanese) tree, the last referring specifically to P. tomentosa. Many varieties, interspecific hybrids, and clonal selections with a better performance than the parental species are presently available and are being used in managed commercial plantings, mainly for timber production. Moreover, sterile clones have been selected to prevent these plants from becoming invasive in new areas where extensive commercial plantings for wood production are established. From an economic point of view, paulownias are multipurpose trees as they are utilized for obtaining large quantities of leafy biomass for fodder, fertilizer, and as mulch to control soil erosion, flowers for the production of honey (Figure 1), as well as short-rotation tree crops for the production of biomass and timber $[3,8,9]$.

Paulownias, in general, are characterized by their fast growth, ability to re-sprout rapidly after cutting, as well as tolerance to drought and high soil acidity. Moreover, paulownias are efficient nitrogen fixers in temperate climates. Recently, in several European countries, including Spain, France, Italy, Rumenia, Bulgaria, Moldovia, Serbia, and Poland, there has been a renewed economic interest in paulownias as an agroforestry crop and there are private companies that publicize new patented clones, produce and sell nursery plants, and give advice to farmers on how to plant and grow them. It is estimated that during the last ten years around 1500 ha of paulownias have been planted in Italy but there are no official figures on this.

There is little information on infectious diseases of paulownias and most of those reported so far are caused by fungi and oomycetes [4,10-13].

In June 2018, a severe disease was noticed in a commercial, intensively managed paulownia planting for the production of timber in the Calabria region (Southern Italy). Symptoms were suggestive of Phytophthora root and crown rot, the common name of a disease affecting several herbaceous and woody plant species. There are diverse Phytophthora species causing this disease, which all provoke very similar symptoms $[12,14]$. The present study was aimed at identifying the etiology of this disease of paulownia. 

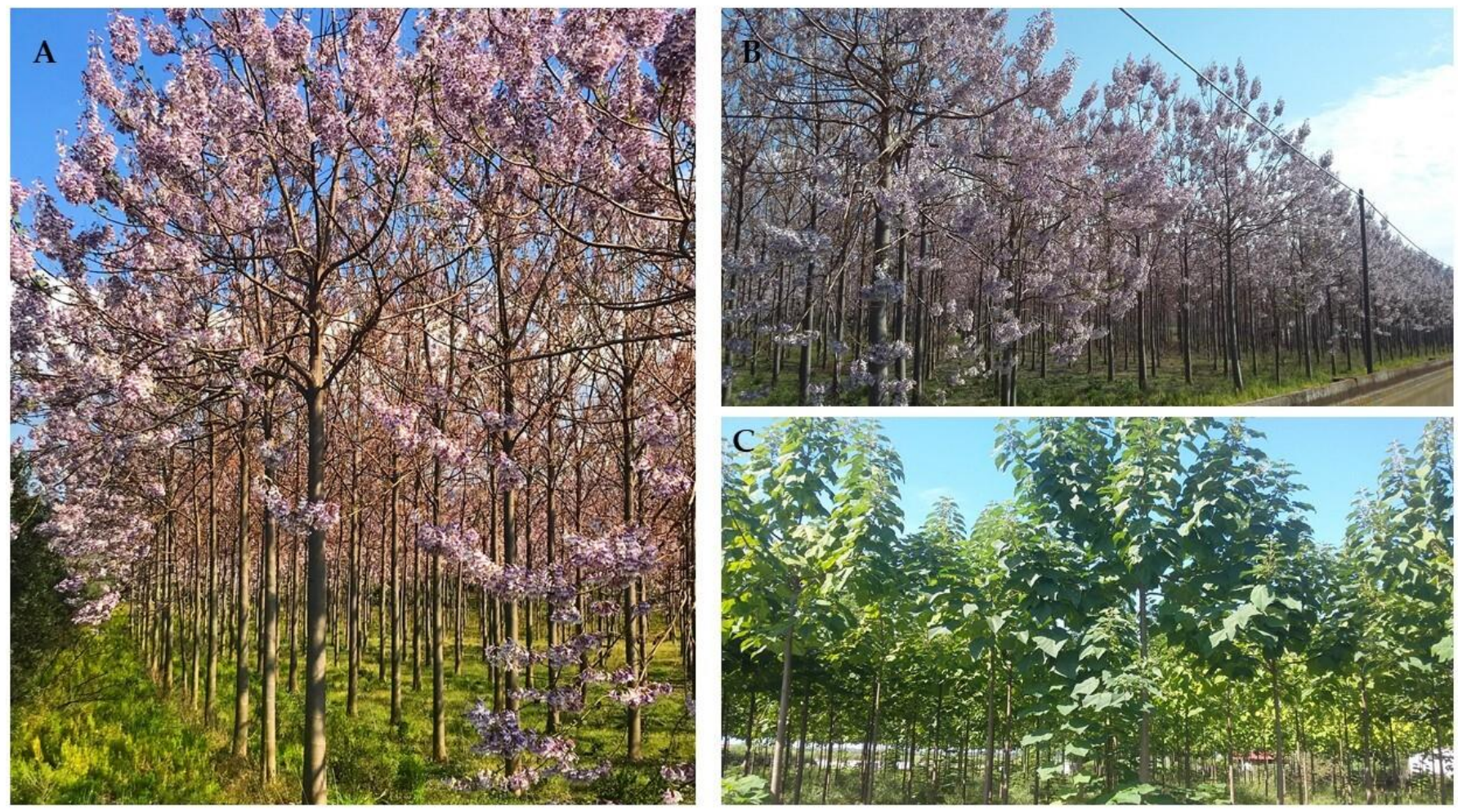

Figure 1. (A,B) Blossoming commercial plantations of paulownia in Calabria (Southern Italy). (C) A commercial paulownia plantation in summer (Calabria).

\section{Materials and Methods}

\subsection{Isolation and Morphological Identification of Isolates}

In June 2018, a 2-year-old planting of Paulownia elongata $\times$ P. fortunei in the municipality of Montalto Uffugo, province of Cosenza, Calabria region (Southern Italy) (Geographic Coordinates, DATUM WGS 84: $39^{\circ} 39^{\prime} 58.0^{\prime \prime} \mathrm{N}, 16^{\circ} 21^{\prime} 25.5^{\prime \prime} \mathrm{E}$, Cosenza, Calabria, Southern Italy) was visited by the research group for the first time. The plantation extended for about 1 ha with tree spacing of $4 \times 6 \mathrm{~m}$ and clay-loam soil. Plants were watered with a drip irrigation system and water was from a well pumping from groundwater table. Potted 1-year-old rooted cuttings imported from Bulgaria had been used for the planting in late spring 2016. A second inspection was carried out a year later, in June 2019. In 2018, necrotic roots, stem bark, and rhizosphere soil were sampled from six distinct symptomatic Paulownia elongata $\times P$. fortunei trees in a commercial orchard at Montalto Uffugo, in the province of Cosenza.

Bark pieces and root segments were washed thoroughly in tap water, disinfected in $1 \% \mathrm{NaClO}$ for $2 \mathrm{~min}$ and immersed in $70 \% \mathrm{EtOH}$ for $30 \mathrm{~s}$, rinsed in sterile distilled water, dipped dry, and plated on selective PARPNH V8-agar medium which consisted of $100 \mathrm{~mL}$ V8 juice (Campbell Grocery Products Ltd., Ashford, UK), 15 g agar, $3 \mathrm{~g} \mathrm{CaCO}_{3}, 200 \mathrm{mg}$ ampicillin, $10 \mathrm{mg}$ rifampicin, $25 \mathrm{mg}$ pentachloronitrobenzene (PCNB), $50 \mathrm{mg}$ nystatin, $50 \mathrm{mg}$ hymexazol, and $1 \mathrm{~L}$ of deionized water [12]. After an incubation period of $24-48 \mathrm{~h}$ in the dark at $24^{\circ} \mathrm{C}$, pure cultures were obtained by transferring individual growing hyphae to V8-juice agar (V8A) [15].

Rhizosphere soil samples, including fine roots, were collected under the canopy of Paulownia trees after removing the upper organic soil layer. Soil sampling and isolation were performed in accordance with Riolo et al. [16]: four soil cores were collected from each tree, 50-150 cm away from the stem base, and were bulked together (about $2 \mathrm{~L}$ ). Two subsamples of about $500 \mathrm{~mL}$ were used for baiting tests that were performed in a walk-in growth chamber with $12 \mathrm{~h}$ natural day light at $20^{\circ} \mathrm{C}$. Young leaves of carob-tree (Ceratonia siliqua) and oak (Quercus spp.) floated over flooded soil were used as baits. After $24-48 \mathrm{~h}$ 
incubation, necrotic segments ( $2 \mathrm{~mm}$ side) from symptomatic leaves were plated in Petri dishes onto selective PARPNH agar medium. Petri dishes were incubated at $20^{\circ} \mathrm{C}$ in the dark. Outgrowing Phytophthora hyphae were transferred onto V8 juice agar (V8A) under the stereomicroscope.

Morphological features and colony morphology of all isolates, including the morphology and dimensions of asexual reproductive structures, were determined on colonies grown on V8A at $24-26^{\circ} \mathrm{C}$ in the dark in accordance with standard procedures [12]. Cardinal temperatures for radial growth were determined by growing the isolates on potato dextrose agar (PDA; Oxoid Ltd., Basingstoke, UK) in Petri dishes (9 cm diam.), and incubating the dishes at $5{ }^{\circ} \mathrm{C}, 10^{\circ} \mathrm{C}, 15^{\circ} \mathrm{C}, 20^{\circ} \mathrm{C}, 25^{\circ} \mathrm{C}, 27^{\circ} \mathrm{C}, 30^{\circ} \mathrm{C}, 32{ }^{\circ} \mathrm{C}$, and $35^{\circ} \mathrm{C}$ $\left(\right.$ all $\pm 0.5^{\circ} \mathrm{C}$ ), in the dark. In total, 17 isolates of Phytophthora nicotianae and 24 isolates of Ph. palmivora, with four replicates per isolate and temperature value, were tested. Sporangia production was stimulated with the method described by Santilli et al. [14]. Fragments of $2 \mathrm{~mm}$ were cut from the growing edge of 7-day-old cultures grown in Petri dishes (15 mm diam.) on V8A at $27^{\circ} \mathrm{C}$ in the dark, were placed in a $5 \mathrm{~cm}$ diameter Petri dish and flooded with non-sterile soil extract water (200 g soil suspended in $1 \mathrm{~L}$ of de-ionized water for $24 \mathrm{~h}$ at room temperature and then filtered). After incubation at $27^{\circ} \mathrm{C}$ in the dark for 24-48 h, dimensions and morphological features of 50 mature sporangia of each isolate were determined at $\times 400$ magnification.

\subsection{Molecular Identification of Isolates}

All purified cultures were molecularly identified by the amplification and analysis of an Internal Transcribed Spacer (ITS) of ribosomal DNA (rDNA). Total DNA was extracted from 7-day-old cultures grown on V8-agar at $22{ }^{\circ} \mathrm{C}$ by using the PowerPlant ${ }^{\circledR}$ Pro DNA isolation Kit (MO BIO Laboratories, Inc., Carlsbad, CA, USA), following the manufacturer's instructions. The PCR amplification was performed by using the primer pairs ITS6 $\left(5^{\prime}-\right.$ GAAGGTGAAGTCGTAACAAGG-3') [17] and ITS4 (5'-TCCTCCGCTTATTGATATGC$\left.3^{\prime}\right)$ [18] in a $25 \mu \mathrm{L}$ reaction mix containing PCR Buffer (1X), dNTP mix (0.2 mM), $\mathrm{MgCl} 2$ $(1.5 \mathrm{mM})$, forward and reverse primers $(0.5 \mu \mathrm{M}$ each), Taq DNA Polymerase $(1 \mathrm{U})$, and $100 \mathrm{ng}$ of DNA. The thermo-cycler conditions were as follows: $94{ }^{\circ} \mathrm{C}$ for $3 \mathrm{~min}$; followed by 35 cycles of $94{ }^{\circ} \mathrm{C}$ for $30 \mathrm{~s}, 55^{\circ} \mathrm{C}$ for $30 \mathrm{~s}$, and $72{ }^{\circ} \mathrm{C}$ for $30 \mathrm{~s}$; and then $72{ }^{\circ} \mathrm{C}$ for $10 \mathrm{~min}$. Amplicons were detected in $1 \%$ agarose gel and sequenced in both directions by an external service (Macrogen, Amsterdam, The Netherlands). All the sequences were analyzed by using FinchTV v.1.4.0 [19]. Species identification was performed by blast searches in GenBank [20], Phytophthora database [21] and in a local database containing sequences of ex-type or key isolates from published studies. Isolates were assigned to a species when the respective consensus sequence was $100 \%$ identical to that of a reference isolate.

\subsection{Pathogenicity Tests}

The pathogenicity of the two Phytophthora species, recovered from roots and stem bark of $P$. elongata $\times P$. fortunei trees in Calabria, was tested in two separate experiments, using the soil infestation method as described by La Spada et al. [22] and the method of stem inoculation by wounding as described by Aloi et al. [23], respectively. The isolates C2K3A (Ph. nicotianae) and C1K9E (Ph. palmivora), obtained from rhizosphere soil and roots of symptomatic $P$. elongata $\times P$. fortunei trees, respectively, were used in the soil infestation test. Twelve 2-month-old saplings of $P$. elongata $\times P$. fortunei were transplanted into freedraining pots containing a mixture of autoclaved universal potting soil (Terraricca (C), Cifo Srl, Giorgio di Piano, Bologna, Italy) and inoculum $\left(20 \mathrm{~cm}^{3}\right.$ of inoculum per $1000 \mathrm{~cm}^{3}$ of potting mixture). Inoculum consisted of a 21-day-old culture of the isolates grown in the dark at $25{ }^{\circ} \mathrm{C}$ in a $750 \mathrm{~mL}$ jar containing a sterilized medium made of a mixture of $50 \mathrm{~mL}$ of millet seeds and $50 \mathrm{~mL} \mathrm{V8-juice} \mathrm{broth.} \mathrm{Ten} \mathrm{control} \mathrm{plants} \mathrm{were} \mathrm{transplanted} \mathrm{in}$ free-draining pots containing non-infested potting mixture. After transplanting, all plants were maintained in saturated soil for $48 \mathrm{~h}$ and then transferred to a growth chamber at $23{ }^{\circ} \mathrm{C}, 80 \%$ relative humidity, and a photoperiod of $16 \mathrm{~h}$ of light and $8 \mathrm{~h}$ of dark. The trial 
was concluded when inoculated plants showed severe symptoms of wilting, leaf yellowing, and defoliation (6 weeks post inoculation). At the end of the test, both Phytophthora species were re-isolated from necrotic roots and the identity was confirmed by sequencing the ITS. Symptoms were assessed visually. The severity of root rot was rated according to a scale of five root damage classes: 4 = healthy root system with dense fine root system and well developed taproot; $3 \leq 25 \%$ fine root losses and well developed taproot; $2=26 \%-50 \%$ fine root losses, beginning taproot dieback and small necrotic lesions on woody roots and/or the collar; and $1=51 \%-75 \%$ fine root losses, advanced taproot dieback and large necrotic lesions on tap roots and/or the collar; $0=76-100 \%$ fine root losses, extensive taproot dieback and girdling necrotic lesions on taproot and/or the collar. The roots were then dried for $72 \mathrm{~h}$ at $65^{\circ} \mathrm{C}$ and the dry weights of main roots (diam 2-10 mm) and fine roots (diam $<2 \mathrm{~mm}$ ) were recorded for each plant [24]. Data were analyzed using one-way ANOVA followed by Dunnett's multiple comparisons test by using R software. Differences at $p \leq 0.05$ were considered significant.

The pathogenicity of a Ph. nicotianae isolate and a Ph. palmivora isolate (P4K1C7 and P3K4A9, respectively), both from stem bark, was tested by wound inoculating on the stems of 6-month-old saplings of $P$. elongata $\times P$. fortunei grown in plastic pots $(10 \mathrm{~cm}$ diameter, $1 \mathrm{~L}$ volume). Six saplings were inoculated with each isolate, and four were used as control. The basal stem, near the collar, was disinfected with 70\% ethanol, and a disk of bark (5 mm diameter) was removed with a flamed cork borer and replaced with an agar-mycelium plug taken from the margin of an actively growing colony on V8A as described by Aloi et al. [23]. The wound was covered by putting the excised bark disk back on the wound and then sealing it tightly with Parafilm ${ }^{\circledR}$. The stem of each sapling was inoculated $10 \mathrm{~cm}$ above soil level with a single hole per stem. A sterile V8A plug was inserted into the wound of control saplings as described above. All inoculated seedlings were watered regularly for 30 days and kept in a growth chamber at $23{ }^{\circ} \mathrm{C}, 80 \%$ relative humidity, and a photoperiod of $16 \mathrm{~h}$ of light and $8 \mathrm{~h}$ of dark. The trial was concluded when inoculated plants showed severe symptoms of stem necrosis (4 weeks post inoculation). The length of necrotic lesion originating from each inoculation point was measured after removing the bark and both Phytophthora species were re-isolated from necrotic lesions using the selective PARPNH V8-agar medium and sequenced.

\section{Results}

\subsection{Symptoms of the Disease}

The first disease symptoms, including leaf chlorosis, wilting and stunting, were noticed by the farmer on just a few scattered plants in 2016, a few weeks after planting. When we made the first access, in June 2018 , about $40 \%$ of the trees showed more or less severe above-ground symptoms including wilting, stunting, leaf yellowing, defoliation, basal stem necrosis, and final death of the entire plant (Figure 2). Occasionally, a viscous, dark brown, sticky exudate oozed from the basal part of non-lignified stems (Figure 3). Above-ground symptoms were always associated with severe root rot and often with basal stem necrosis (crown rot). By 2019, the overall number of symptomatic and dead trees had not increased, but symptoms had progressed and worsened in surviving trees compared to those observed in 2018. Conversely, no symptoms were observed in young saplings of P. elongata $\times P$. fortunei from a local nursery that had been transplanted in 2018 to replace dead trees. 

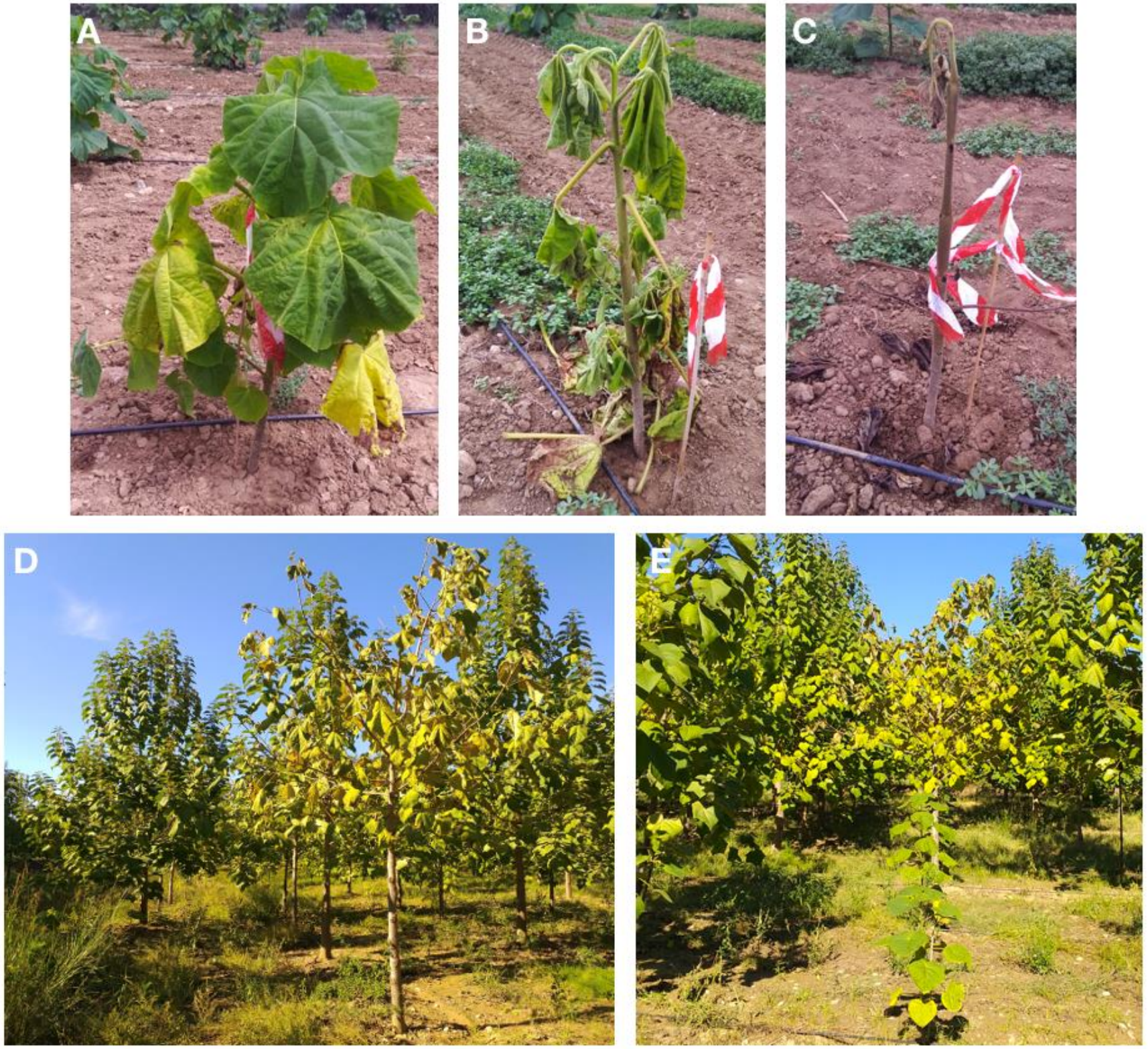

Figure 2. (A-C) Symptoms of wilting, stunting, leaf yellowing, defoliation, and final death of the entire plant in a young plantation of paulownia (Paulownia elongata $\times$ P. fortunei) in Calabria. (D,E) Leaf chlorosis, wilting, and stunting in 4-year-old trees (June 2019). (E) In the foreground, asymptomatic sapling from a different nursery transplanted in 2018 to replace a dead tree.

\subsection{Morphological Characterisitcs of Phytophthora Isolates}

Direct isolation from rotten roots and basal stem bark of six symptomatic trees selected randomly in the plantation of Montalto Uffugo consistently yielded two Phytophthora species with distinct colony morphologies on solid culture media (Figure 4). 

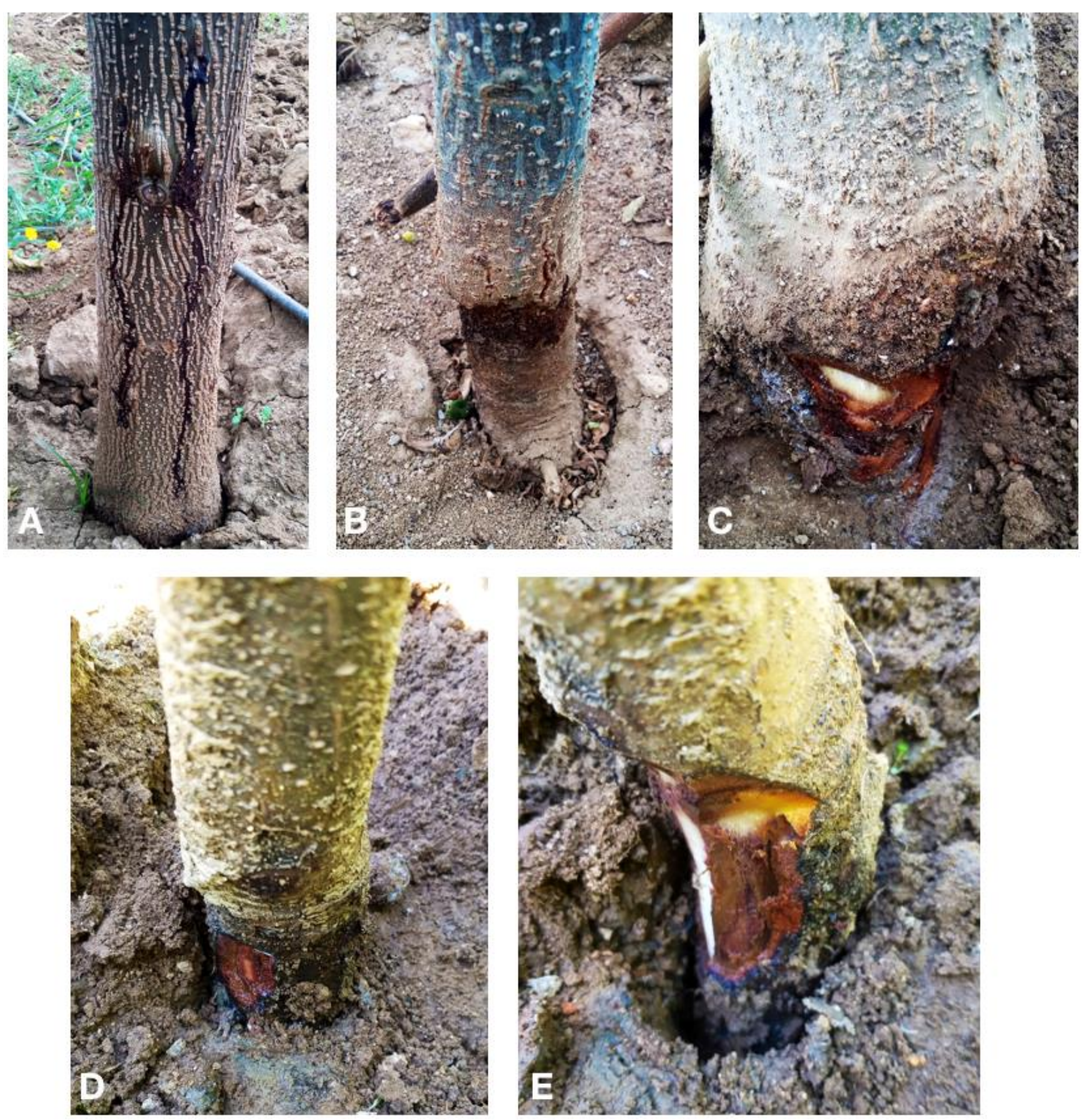

Figure 3. (A) Basal stem necrosis with dark brown, sticky exudate on Paulownia elongata $\times$ P. fortunei trees. (A-C). Symptoms of severe crown rot on young trees (June 2018). (D,E). Symptoms of severe crown rot on 3-year-old trees (June 2019). 


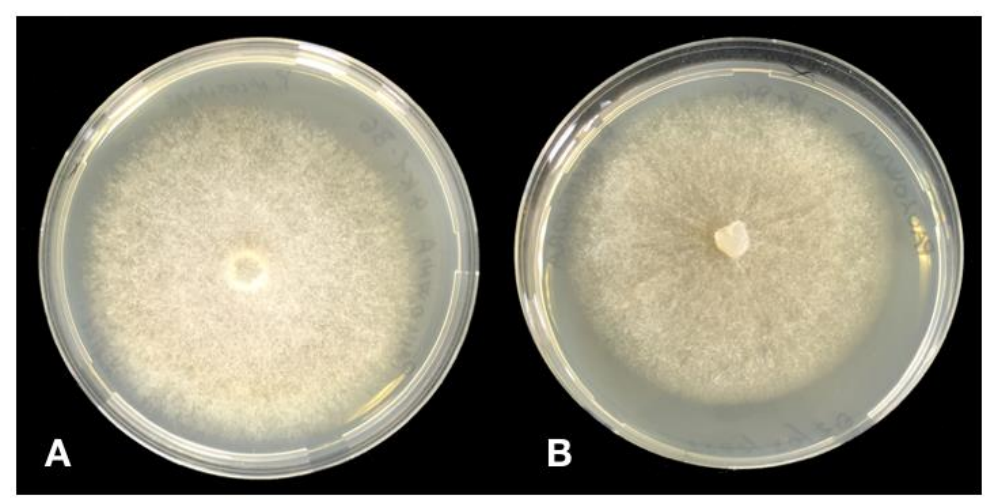

Figure 4. Morphology of 7-day-old colonies of Ph. nicotianae (A) and Ph. palmivora (B) grown on V8A at $25^{\circ} \mathrm{C}$ in the dark.

The first species, identified subsequently as $P h$. nicotianae, was recovered exclusively from basal stem bark, while the second species, identified subsequently as Ph. palmivora, was recovered from both roots and in lower proportion from basal stem bark. Both species were recovered from all six symptomatic plants. The proportions of isolates of each species recovered by direct isolation from stem bark were $70 \%$ and $30 \%$, respectively. Moreover, both species were recovered by leaf-baiting from rhizosphere soil of symptomatic plants in proportions of 53\% and 47\%, respectively. Overall, 41 single-hypha isolates (17 and 24 isolates of each species, respectively) were selected randomly to be characterized (Table 1). On V8 agar (V8A) Ph. nicotianae formed fluffy colonies, with dense and cottony aerial mycelium. Colonies on PDA were typically arachnoid. They grew between $10{ }^{\circ} \mathrm{C}$ and $32{ }^{\circ} \mathrm{C}$, with an optimum of $27^{\circ} \mathrm{C}$. Colony morphology of Ph. palmivora on V8A was stellate with aerial mycelium and coralloid hyphae. Colonies on PDA were uniform and slightly woolly, with stoloniferous hyphae. Minimum and maximum temperatures for growth were $10^{\circ} \mathrm{C}$ and $35^{\circ} \mathrm{C}$, respectively, while optimum temperature was $27^{\circ} \mathrm{C}$. Colonies grew more slowly than those of Ph. nicotianae. On both solid V8A and V8A plugs flooded with non-sterile soil extract, $\mathrm{Ph}$. nicotianae produced persistent, ovoid to spherical, papillate sporangia (dimensions $45.0 \times 34.0$ to $33.1 \times 23.5 \mu \mathrm{m}$ and mean length/breadth ratio 1.4:1), while Ph. palmivora produced ovoid-ellipsoid, caducous, papillate sporangia (dimensions $21.5 \times 33.2$ to $19.2 \times 29.4 \mu \mathrm{m}$ ) with a short (mean length $<5 \mu \mathrm{m}$ ) pedicel. Isolates of both species were self-sterile and did not produce antheridia or oogonia in single cultures.

\subsection{Molecular Identification}

Amplification and sequencing of the Internal Transcribed Spacer (ITS) regions of ribosomal DNA (rDNA) of isolates of the two species recovered from paulownia plants revealed $99 \%-100 \%$ identity with the sequence of Phytophthora nicotianae isolates CBS 31062, CNRnico43RC, IMI 397474 and IMI 398989 (GenBank Accession Number HQ643302, KT148945, GU723474 and HQ596557, respectively [25-28]) and P. palmivora isolates CNRpal44RC, CNRpal72RC, IMI 398987, IMI 398988, CBS 27433, IMI 503890 (MD5), IMI 503891 (MD6) and CBS 305.62 (GenBank Accession Number KT148931, KT148921, HQ596556, HQ596558, and HQ643308, KF823978, KF823979, MG865559, respectively [25-30]). In the tree obtained by the phylogenetic analysis of the combined data set of sequences from ITS region of isolates recovered from paulownia and sequences of Phytophthora species used as references, all isolates from roots, stem bark, and rhizosphere soil of paulownia trees clustered (bootstrap values of 1000 replicate) with the references isolates of these species (Figure 5). In particular, the isolates of Ph. Palmivora from paulownia grouped separately from those of Ph. heterospora [31], a very recently described sister species of Ph. palmivora sensu stricto segregated from the Ph. palmivora complex (Figure 5). The ITS sequences of isolates from roots, bark and rhizosphere soil of paulownia were deposited in GenBank (the respective GenBank accession numbers are given in Table 1). 


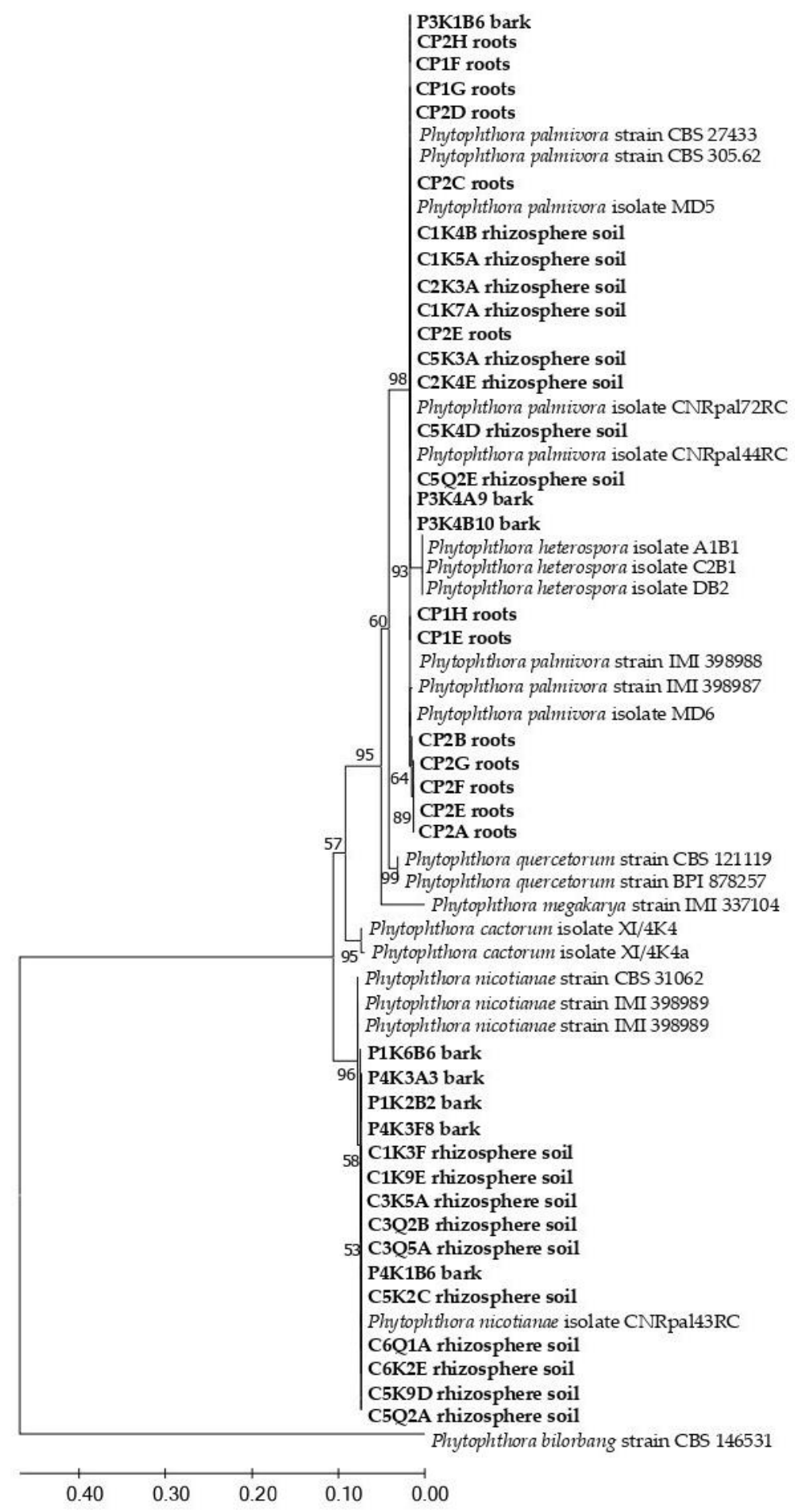

Figure 5. Phylogenetic tree for the ITS loci obtained by the maximum likelihood method, based on the Tamura-Nei model. Relationships between the 41 Phytophthora spp. Isolates from paulownia (in bold), the reference isolates of Ph. nicotianae and Ph. palmivora and other Phytophthora species within the ITS Clade 1 and Clade 4, including Ph. heterospora very recently separated from Ph. palmivora. Ph. bilorbang (CBS 146531) was used as outgroup taxon. The bootstrap consensus tree inferred from 1000 replicates is taken to represent the evolutionary history of the taxa analyzed. Branches corresponding to partitions reproduced in less than $50 \%$ bootstrap replicates are collapsed. The percentage of replicate trees in which the associated taxa clustered together in the bootstrap test are shown next to the branches. The tree is drawn to scale, with branch lengths measured in the number of substitutions per site (below the branches). 
Table 1. Isolates of Phytophthora nicotiane and Ph. palmivora sourced from different tissue of Paulownia elongata $\times P$. fortunei trees in Calabria, characterized in this study.

\begin{tabular}{|c|c|c|c|}
\hline Isolate Code & Phytophthora Taxa & Source & Accession Number \\
\hline & & & ITS \\
\hline P4K1C7 & Ph. nicotianae & Bark & OK463579 \\
\hline P4K3A3 & Ph. nicotianae & Bark & OK463580 \\
\hline P1K2B2 & Ph. nicotianae & Bark & OK463581 \\
\hline P4K1B6 & Ph. nicotianae & Bark & OK463582 \\
\hline P1K6B6 & Ph. nicotianae & Bark & OK463583 \\
\hline P4K3F8 & Ph. nicotianae & Bark & OK463584 \\
\hline P1K4A3 & Ph. nicotianae & Bark & OK463585 \\
\hline P3К 4A9 & Ph. palmivora & Bark & OK463586 \\
\hline P3K1B6 & Ph. palmivora & Bark & OK463587 \\
\hline P3К4B10 & Ph. palmivora & Bark & OK463588 \\
\hline C1K9E & Ph. nicotianae & Rhizosphere soil & OK463589 \\
\hline $\mathrm{C} 1 \mathrm{~K} 3 \mathrm{~F}$ & Ph. nicotianae & Rhizosphere soil & OK463590 \\
\hline $\mathrm{C} 3 \mathrm{~K} 5 \mathrm{~A}$ & Ph. nicotianae & Rhizosphere soil & OK463591 \\
\hline C3Q5A & Ph. nicotianae & Rhizosphere soil & OK463592 \\
\hline C3Q2B & Ph. nicotianae & Rhizosphere soil & OK463593 \\
\hline $\mathrm{C} 5 \mathrm{~K} 2 \mathrm{C}$ & Ph. nicotianae & Rhizosphere soil & OK463594 \\
\hline C5K9D & Ph. nicotianae & Rhizosphere soil & OK463595 \\
\hline C5Q2A & Ph. nicotianae & Rhizosphere soil & OK463596 \\
\hline C6Q1A & Ph. nicotianae & Rhizosphere soil & OK463597 \\
\hline C6К2E & Ph. nicotianae & Rhizosphere soil & OK463598 \\
\hline $\mathrm{CP} 1 \mathrm{~F}$ & Ph. palmivora & Roots & OK463599 \\
\hline $\mathrm{CP} 2 \mathrm{H}$ & Ph. palmivora & Roots & OK463600 \\
\hline $\mathrm{CP} 2 \mathrm{~A}$ & Ph. palmivora & Roots & OK463601 \\
\hline $\mathrm{CP} 2 \mathrm{G}$ & Ph. palmivora & Roots & OK463602 \\
\hline $\mathrm{CP} 1 \mathrm{H}$ & Ph. palmivora & Roots & OK463603 \\
\hline $\mathrm{CP} 1 \mathrm{G}$ & Ph. palmivora & Roots & OK463604 \\
\hline CP2D & Ph. palmivora & Roots & OK463605 \\
\hline $\mathrm{CP} 2 \mathrm{~F}$ & Ph. palmivora & Roots & OK463606 \\
\hline $\mathrm{CP} 2 \mathrm{E}$ & Ph. palmivora & Roots & OK463607 \\
\hline $\mathrm{CP} 2 \mathrm{~B}$ & Ph. palmivora & Roots & OK463608 \\
\hline CP1E & Ph. palmivora & Roots & OK463609 \\
\hline $\mathrm{CP} 2 \mathrm{C}$ & Ph. palmivora & Roots & OK463610 \\
\hline $\mathrm{C} 1 \mathrm{~K} 5 \mathrm{~A}$ & Ph. palmivora & Rhizosphere soil & OK463611 \\
\hline $\mathrm{C} 1 \mathrm{~K} 4 \mathrm{~B}$ & Ph. palmivora & Rhizosphere soil & OK463612 \\
\hline C1K7A & Ph. palmivora & Rhizosphere soil & OK463613 \\
\hline $\mathrm{C} 2 \mathrm{~K} 3 \mathrm{~A}$ & Ph. palmivora & Rhizosphere soil & OK463614 \\
\hline $\mathrm{C} 2 \mathrm{~K} 5 \mathrm{~B}$ & Ph. palmivora & Rhizosphere soil & OK463615 \\
\hline $\mathrm{C} 2 \mathrm{~K} 4 \mathrm{E}$ & Ph. palmivora & Rhizosphere soil & OK463616 \\
\hline C5K3A & Ph. palmivora & Rhizosphere soil & OK463617 \\
\hline C5K4D & Ph. palmivora & Rhizosphere soil & OK463618 \\
\hline C5Q2E & Ph. palmivora & Rhizosphere soil & OK463619 \\
\hline
\end{tabular}

\subsection{Pathogenicity Test}

The isolates C2K3A of Ph. nicotianae and C1K9E of Ph. palmivora from P. elongata $\times$ P. fortunei proved to be pathogenic on saplings of the same plant species. All 12 seedlings of P. elongata $\times$ P. fortunei transplanted into pots filled with soil infested with the two Phytophthora species developed severe symptoms of root rot, leaf chlorosis, defoliation, wilt, and death within four weeks after the transplanting (Figure 6). Conversely, control plants remained asymptomatic. 

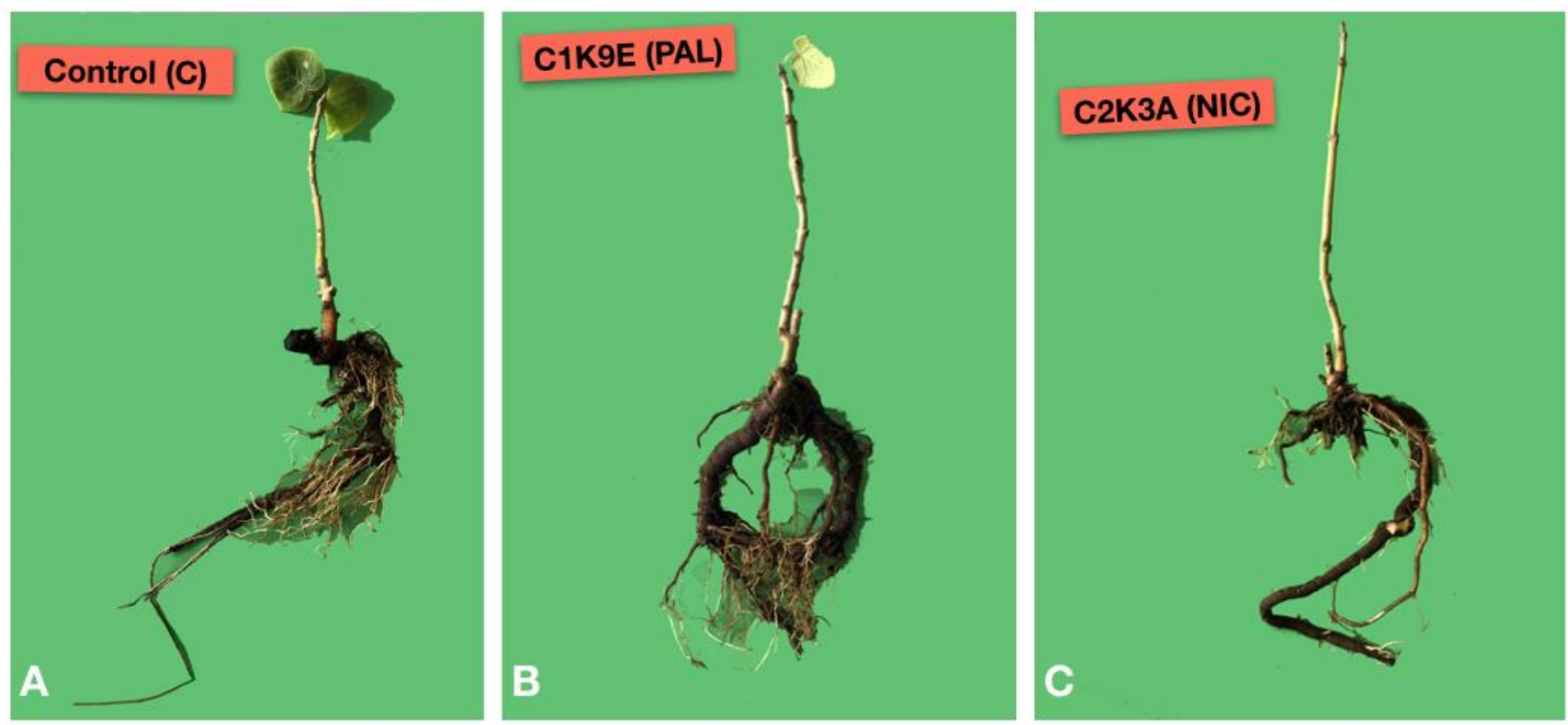

Figure 6. (A) No symptoms appeared in control Paulownia elongata $\times$ P. fortunei saplings 6 weeks after transplanting in uninfested soil; (B). Symptoms of root rot, leaf chlorosis, defoliation, wilt, and death on saplings 6 weeks after transplanting in soil infested with Phytophthora palmivora (C1K9E), and in (C). with Ph. Nicotianae (C2K3A).

The fine root/main root weight (frw/mrw) ratio in control plants and their root damage class were 1.2 and $3.8 \pm 0.50$, respectively (Figure 7). Phytophthora nicotianae was the most aggressive species causing $70 \%$ mortality of saplings 6 weeks after the transplanting, a $\mathrm{frw} / \mathrm{mrw}$ ratio of 0.39 (67.5\% reduction compared to the control), $74 \%$ reduction in fine root weight compared to control and a root damage class of $1.3 \pm 0.46$ (i.e., $67.5 \%$ fine root losses, severe decay of taproot and collar necrosis) (Figure 6). Phytophthora palmivora caused $30 \%$ mortality, a frw $/ \mathrm{mrw}$ ratio of 0.74 (38.3\% reduction compared to the control), and a root damage class of $2.0 \pm 1.0$ (Figure 6). Differences in root damage class and frw $/ \mathrm{mrw}$ ratio compared to the control were statistically significant for both isolates C2K3A (Ph. nicotianae) and C1K9E (Ph. palmivora) $(p<0.001)$. Phytophthora nicotianae and Ph. Palmivora were re-isolated from roots of plants expressing symptoms, thus fulfilling Koch's postulates. The identity of isolates obtained from necrotic roots of symptomatic, artificially inoculated saplings was determined by the colony morphology, microscopic observations, and rDNA ITS sequencing. Isolates of Ph. nicotianae and Ph. palmivora from bark proved to be pathogenic on stems of P. elongata $\times$ P. fortunei saplings. All inoculated saplings showed dark brown inner bark lesions that spread up and down from the inoculation wound along the stem and extended to the outer layers of wood. Control plants remained asymptomatic (Figure 8). At the end of the experiment, mean lesion length from all seedlings was recorded. The lesions caused by both Phytophthora species were significantly larger than control plants, but did not differ significantly from each other (Figure 9). Both inoculated species were re-isolated from stem lesions. 


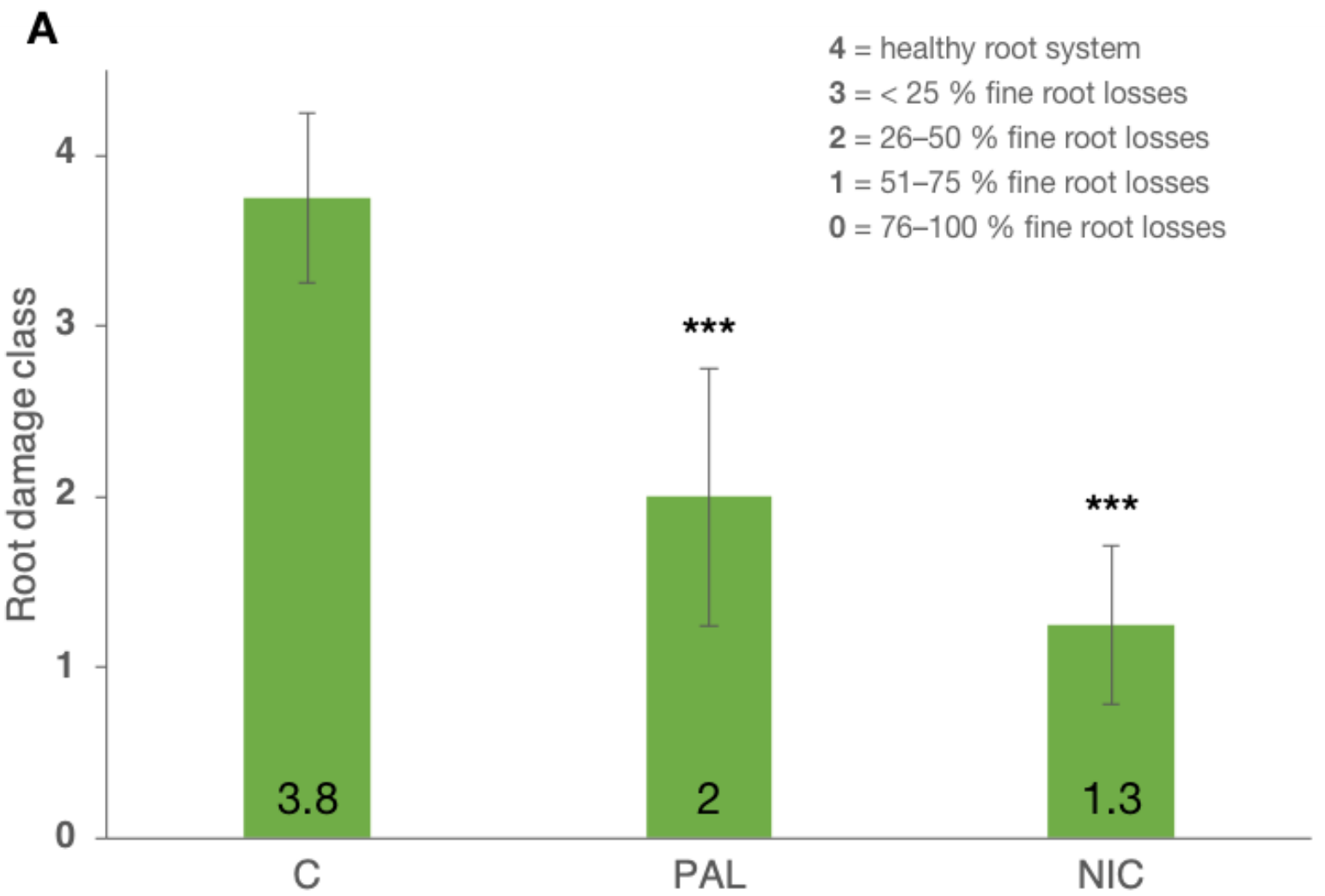

B

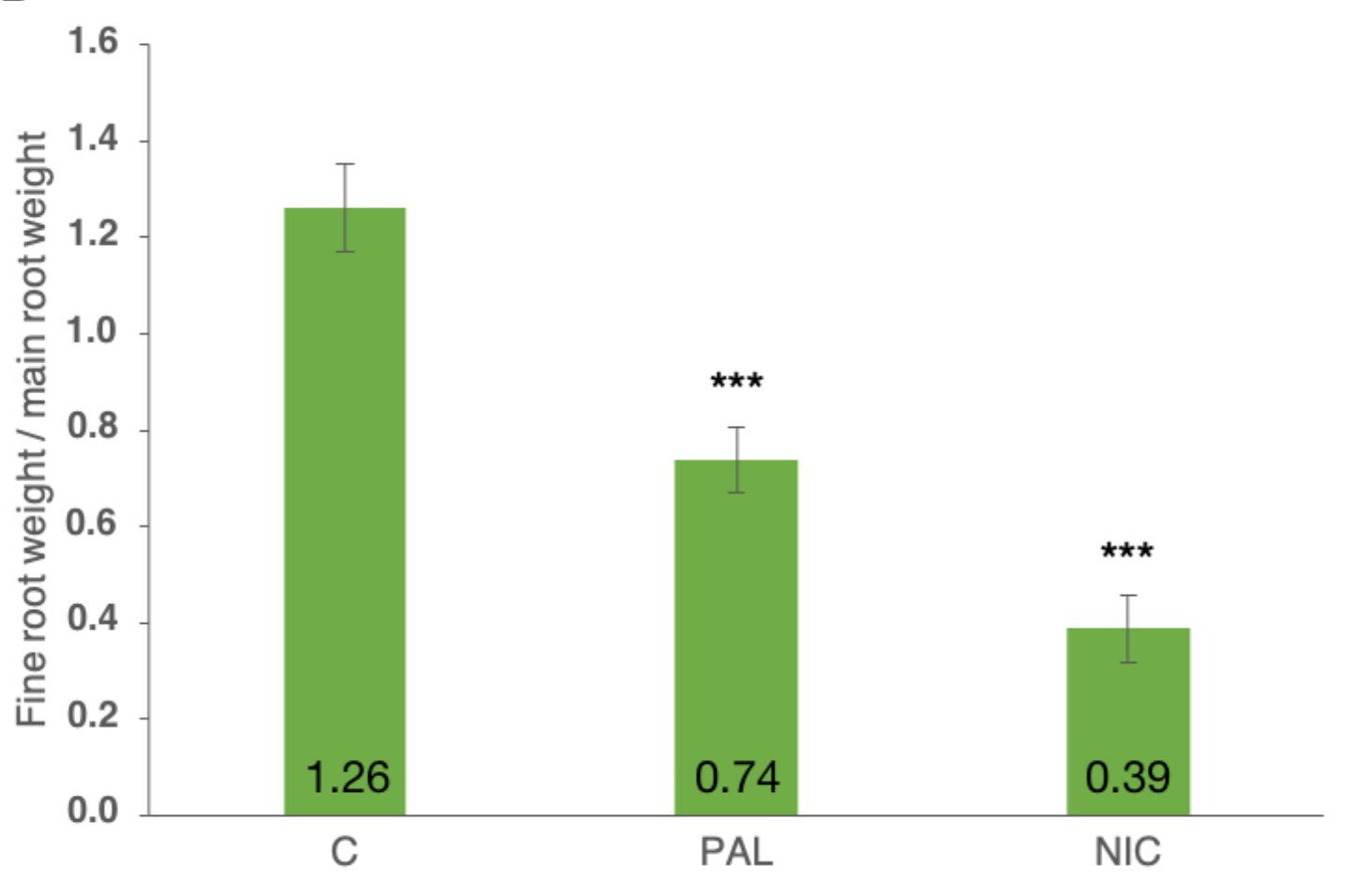

Figure 7. Mean root damage class (A) and mean fine root weight/main root weight (B) ratio of Paulownia elongata $\times$ P. fortunei saplings 6 weeks after transplanting in uninfested soil (Control: C) and in soil infested with Phytophthora nicotianae (NIC) and Ph. palmivora (PAL), singularly. Bars show standard deviations; asterisks represent statistical significances $(* * *=p<0.001)$. 


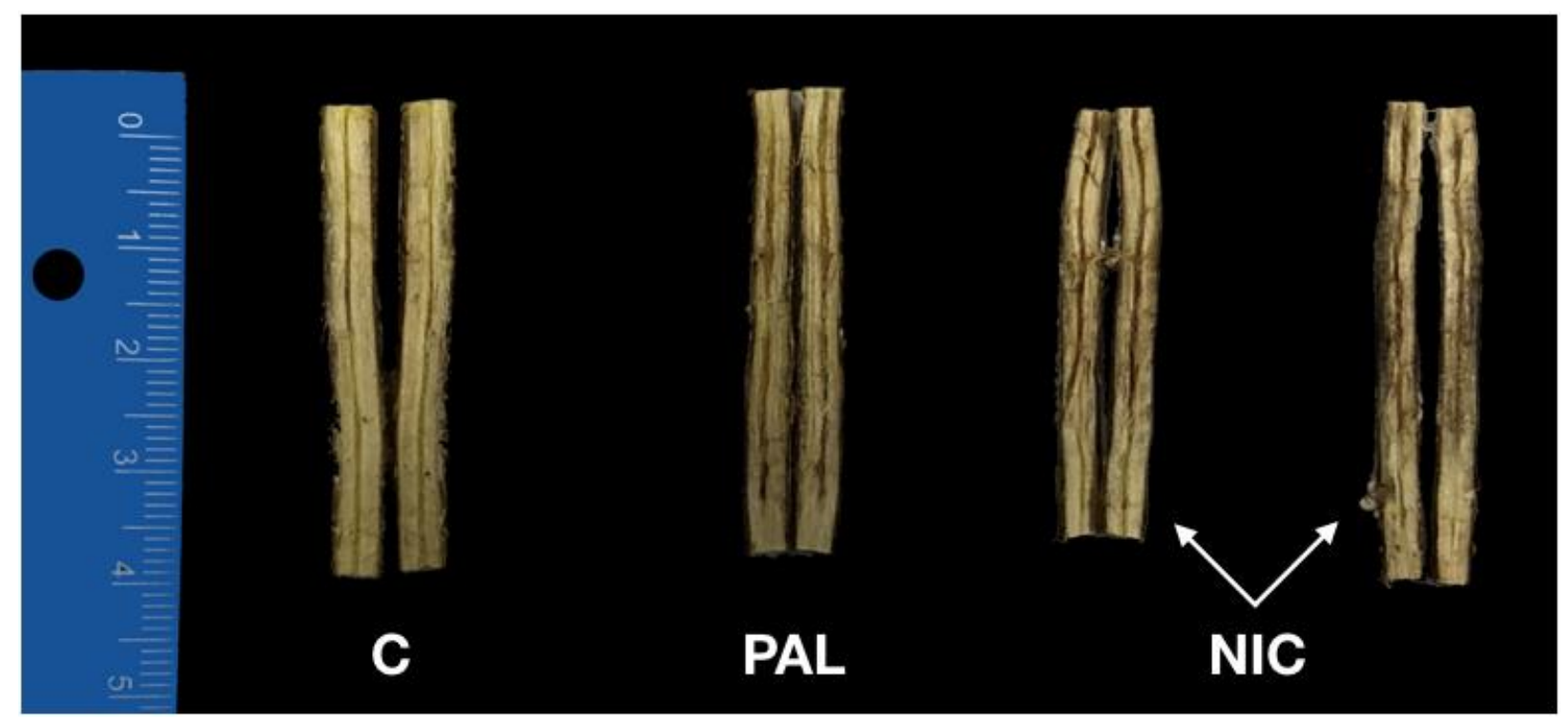

Figure 8. Internal stem necrosis from representative samples of Paulownia elongata $\times$ P. fortunei saplings non-inoculated (C) or inoculated with Phytophthora palmivora (PAL) and Ph. nicotianae (NIC) observed using a zoom stereomicroscope when inoculated plants showed severe symptoms of stem necrosis (4 weeks post inoculation).

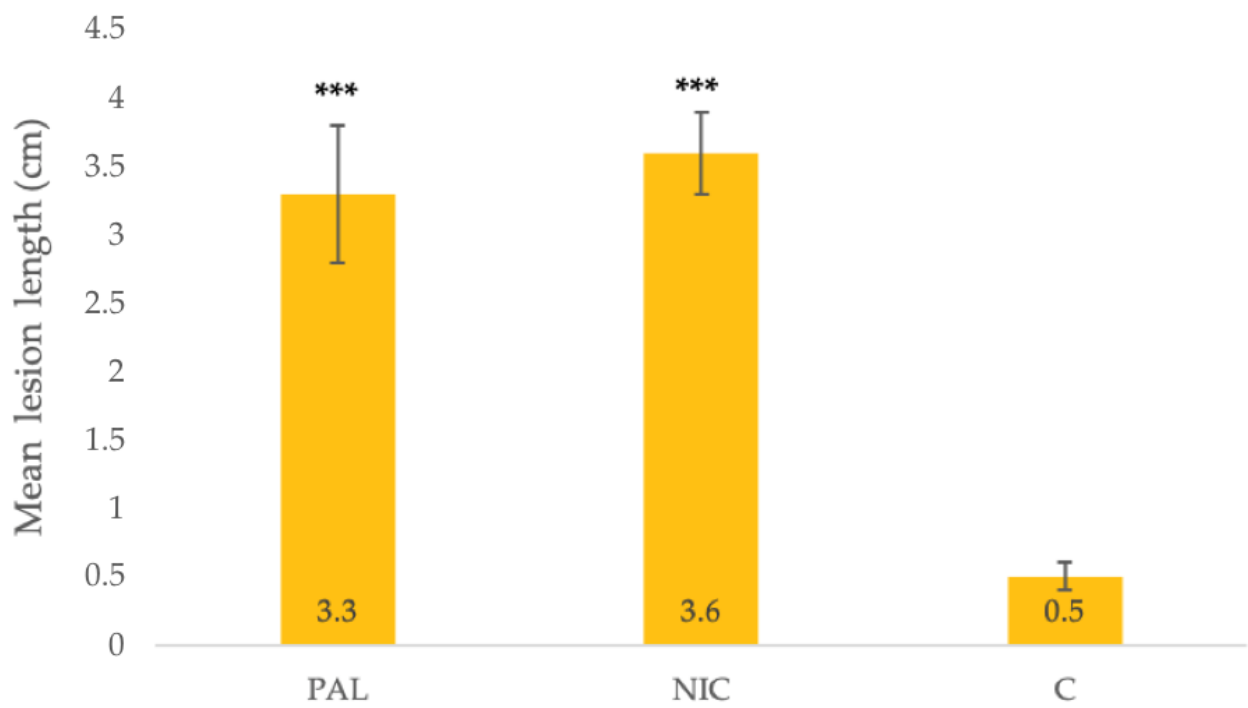

Figure 9. Mean lesion length $( \pm \mathrm{SD})$ of Paulownia elongata $\times$ P. fortunei saplings 4 weeks after wound inoculation on the stem with Ph. nicotianae (NIC), Ph. palmivora (PAL) and control (with a sterile V8A plug). Bars show standard deviations; asterisks represent statistical significances $(* * *) p<0.05)$.

\section{Discussion}

In this study, it was demonstrated that mixed infections of P. nicotianae, from Phytophthora clade 1, and Ph. palmivora, from Phytophthora clade 4, were responsible for the outbreak of Phytophthora crown and root rot of P. elongata $\times$ P. fortunei trees observed in a commercial plantation in Calabria. The etiological role of these two species was proved by completing Koch's postulates. Results of pathogenicity tests indicated that both species were able to induce stem cankers and root rot when inoculated singularly. Although both species were recovered from rhizosphere soil of symptomatic paulownia trees, Ph. nicotianae was isolated more frequently from stem bark than Ph. palmivora while the latter was the only species isolated directly from roots of trees with natural infections. This is in agreement with previous reports indicating P. palmivora is an aggressive pathogen 
of roots of different woody host plants both alone and in combination with other pathogens or pests $[25,32,33]$. Mixed infections of different Phytophthora species on the same host plant are common [34-36]. In these cases, the prevalence as well as the incidence and isolation frequency of each species, and its distribution in different organs of the plant depends on several factors including, among others virulence and ecology of the species itself [36]. Mixed infections on the same host plant produce complex interactions resulting in synergism between pathogens or alternatively additive or neutral effects. Even though simultaneous infections by more than a single pathogen of the same genus or different genera in plants are frequent in natural conditions, the complex phenotypic and genetic responses of plants to multiple infections are still scarcely known. However, they are receiving increasing attention, and recent studies focused also on co-infections by species of Phytophthora $[37,38]$.

Ph nicotianae and Ph. palmivora are polyphagous pathogens with a host range encompassing plant species of different families [39-44]. In Italy, Ph. nicotianae is widespread and is prevalently associated with agricultural crops. Its host range includes several economically important crops, such as citrus, tobacco, and vegetables. It is also the prevalent Phtytophthora species in nurseries of ornamentals [45,46]. Occasionally, it was also recovered from natural and forest ecosystems [16]. During the last twenty years, in the Mediterranean region the number of reports of $P h$. palmivora, an exotic species probably native to the tropics, has increased noticeably. However, it is likely that many of these records refer to $P h$. heterospora, a recently described sister species of Ph. palmivora [31]. Phylogenetic differences between these two species include 3-4 fixed polymorphisms of ITS. Accordingly, in the phylogenetic tree for the ITS loci obtained in this study the isolates from paulownia clustered separately from $P$. heterospora reference isolates and grouped together (100\% similarity) with reference isolates of Ph. palmivora sensu strictu. Moreover, the isolates from paulownia were confidently identified as Ph. palmivora as they did not produce pseudo-conidia on solid medium, a unique distinctive trait of Ph. heterospora, and showed a maximum growth temperature of $35^{\circ} \mathrm{C}$, another key difference between Ph. palmivora and Ph. heterospora [31].

Although both Ph. nicotianae and Ph. palmivora are listed among the pathogens of paulownias in Asia, they were identified only on the basis of morphological characters and their impact on paulownia plantations has not been quantified [11]. Ph. nicotianae was also reported on paulownia in India [47], but as causal agent of leaf blight, a symptom not observed in Calabria. In a list of garden trees and shrubs susceptible to Phtytophthora root and crown rot published by the Royal Horticultural Society, paulownia is classified as a host plant affected only occasionally [48]. To our knowledge, this is the first documented report of Phtytophthora root and crown rot of paulownia in Europe and the first time ever that Phytophthora species associated with this disease have been identified using both morphological and molecular criteria. The severity of the outbreak of this emergent disease observed in Calabria indicates it is a potential threat for the expanding paulownia industry of some European countries and may have phytosanitary implications for the international trade of paulownia plantlets. In fact, $\mathrm{Ph}$. nicotianae and $\mathrm{Ph}$. palmivora as pathogens associated with paulownia are included in the list of quarantine or regulated pathogens by several countries, such as New Zealand and Sudan $[49,50]$.

Although both $\mathrm{Ph}$. nicotianae and $\mathrm{Ph}$. palmivora are already established pathogens in Italy, it can be speculated that the outbreak of Phtytophthora root and crown rot of paulownia observed in Calabria originated from imported nursery plants. This hypothesis is based on circumstantial evidence, including the early appearance of first symptoms soon after planting, the uniform distribution of symptomatic trees throughout the entire plantation and the absence of symptoms on young plants supplied by a local nursery used to replace dead trees. The transport with infected nursery plants has proven to be the primary cause of the spread of Phytophthora species and their introduction into agricultural and forest ecosystems [31,51-56]. Likely, Phytophthora root and crown rot may be particularly harmful in nurseries and new plantings as young plants of paulownia 
are more susceptible than mature trees to infections by Phytophthora species. Moreover, the intensive use of irrigation in nurseries and new plantings may favor the infections by these oomycetes. The use of healthy nursery plants is crucial for preventing this disease in commercial plantations. Paulownias are water-demanding trees and in Mediterranean climate watering is critical for the successful establishment of the planting and afterwards during hot dry summers to promote vigorous growth. In these intensively managed plantations another source of Phytophthora inoculum might be the irrigation water especially if it is recycled or comes from superficial reservoirs [30,57,58], which was not the case of the paulownia planting in Calabria. Soil waterlogging is conducive for Phytophthora root and crown rot. As a consequence, the choice of well-drained soil for establishing new plantings and careful management of irrigation are part of the strategy to prevent the disease. An additional aspect which is worth investigating is the susceptibility to this emerging disease of the new hybrid clones of paulownia selected mainly for their agronomic performance and the technological characteristics of the timber.

Author Contributions: Conceptualization, S.O.C., A.P., R.F. and S.M.; methodology, A.P., S.O.C. and R.F.; software, F.A., M.R. and G.B.; validation, S.O.C., A.P., E.S., F.L.S. and S.M.; formal analysis, M.R., R.F., F.L.S. and F.A.; investigation, F.A., M.R., F.L.S. and G.B.; resources, S.O.C. and A.P.; data curation, M.R. and F.A.; writing-original draft preparation, M.R. and F.A.; writing-review and editing, S.O.C., A.P. and E.S.; visualization, S.O.C.; supervision, S.O.C., S.M., R.F., E.S. and A.P.; project administration, S.O.C. and A.P.; funding acquisition, S.O.C., A.P. and R.F. All authors have read and agreed to the published version of the manuscript.

Funding: This research was funded by the University of Catania, Italy "Investigation of phytopathological problems of the main Sicilian productive contexts and eco-sustainable defense strategies (MEDIT-ECO)" PiaCeRi-PIAno di inCEntivi per la Ricerca di Ateneo 2020-22 linea 2" "5A722192155 "; "F.A. has been granted a Ph.D. fellowship "Scienze Agrarie, Alimentari, Forestali e Ambientali-XXXIII cycle", University of Palermo; M.R. has been granted a fellowship by CREA "OFA" (Rende, Italy), this study is part of his activity as Ph.D., in "Agricultural, Food, and Forestry Science", University Mediterranea of Reggio Calabria, XXXV cycle".

Acknowledgments: We are grateful to F. Di Biase and his family for allowing us to collect samples in their farm, to R. De Leo for useful information on the cultivation of paulownia in Calabria, and to A. Davies for the English revision of the text.

Conflicts of Interest: The authors declare no conflict of interest. The funders had no role in the design of the study; in the collection, analyses, or interpretation of data; in the writing of the manuscript, or in the decision to publish the results.

\section{References}

1. Chase, M.W.; Christenhusz, M.J.M.; Fay, M.F.; Byng, J.W.; Judd, W.S.; Soltis, D.E.; Mabberley, D.J.; Sennikov, A.N.; Soltis, P.S.; Stevens, P.F.; et al. An update of the Angiosperm Phylogeny Group classification for the orders and families of flowering plants: APG IV. Bot. J. Linn. Soc. 2016, 181, 1-20.

2. Toshiyuki, N.; DuVal, A.; Schmull, M.; Tchernaja, T.A.; Crane, P.R. Paulownia tomentosa: A Chineseplant in Japan. Curti's Bot. Mag. 2013, 30, 261-274.

3. Bergmann, B.A. Five years of Paulownia field trials in North Carolina. New For. 2003, 25, 185-199. [CrossRef]

4. Pasiecznick, N. Paulownia tomentosa. Invasive Species Compendium; CABI International: Wallingford, UK, 2019; Available online: www.cabi.org/isc (accessed on 19 August 2021).

5. Snow, W.A. Ornamental, crop, or invasive? The history of the Empress tree (Paulownia) in the USA. For. Trees Livelihoods 2015, 24, 85-96. [CrossRef]

6. Global Invasive Species Database. Species Profile Paulownia Tomentosa. 2021. Available online: http://www.iucngisd.org/gisd/ speciesname/Paulownia+tomentosa (accessed on 25 November 2021).

7. Essl, F. From ornamental to detrimental? The incipient invasion of Central Europe by Paulownia tomentosa. Preslia 2007, 79, 377-389.

8. Stewart, W.M.; Vaidya, B.N.; Mahapatra, A.K.; Terrill, T.H.; Joshee, N. Potential use of multipurpose Paulownia elongata tree as an animal feed resource. Am. J. Plant Sci. 2018, 9, 1212-1227. [CrossRef]

9. Ganchev, G.; Ilchev, A.; Koleva, A. Digestibility and energy content of Paulownia (Paulownia elongata S.Y.Hu) leaves. Agric. Sci. Technol. 2019, 11, 307-310. [CrossRef] 
10. Ray, J.D.; Burgess, T.; Malajczuk, N.; Hardy, G.E.S.J. First report of Alternaria blight of Paulownia spp. Australas. Plant Pathol. 2005, 34, 107-109. [CrossRef]

11. Hsieh, H.J. Study on Paulownia diseases found in Taiwan. Bull. Taiwan For. Res. Inst. 1983, 388, 1-24, (In Chinese with an English Summary).

12. Erwin, D.C.; Ribeiro, O.K. Phytophthora Diseases Worldwide; American Phytopathological Society (APS Press): St. Paul, MN, USA, 1996.

13. Milenković, I.; Tomšovský, M.; Karadžić, D.; Veselinović, M. Decline of Paulownia tomentosa caused by Trametes hirsuta in Serbia. Forest Pathol. 2018, 48, e12438. [CrossRef]

14. Santilli, E.; Riolo, M.; La Spada, F.; Pane, A.; Cacciola, S.O. First report of root rot caused by Phytophthora bilorbang on Olea europaea in Italy. Plants 2020, 9, 826. [CrossRef]

15. Jung, T.; Blaschke, H.; Neumann, P. Isolation, identification and pathogenicity of Phytophthora species from declining oak stands. Eur. J. For. Pathol. 1996, 26, 253-272. [CrossRef]

16. Riolo, M.; Aloi, F.; La Spada, F.; Sciandrello, S.; Moricca, S.; Santilli, E.; Pane, A.; Cacciola, S.O. Diversity of Phytophthora communities across different types of mediterranean vegetation in a nature reserve area. Forests 2020, 11, 853. [CrossRef]

17. Cooke, D.E.; Drenth, A.; Duncan, J.M.; Wagels, G.; Brasier, C.M. A molecular phylogeny of Phytophthora and related oomycetes. Fungal Genet. Biol. 2000, 30, 17-32. [CrossRef]

18. White, T.J.; Bruns, T.; Lee, S.; Taylor, J.W. Amplification and direct sequencing of fungal ribosomal RNA genes for phylogenetics In PCR Protocols: A Guide to Methods and Applications; Innis, M.A., Gelfand, D.H., Sninsky, J.J., White, T.J., Eds.; Academic Press Inc.: San Diego, CA, USA, 1990; Volume 18, pp. 315-322.

19. FinchTV v.1.4.0. Available online: https://digitalworldbiology.com/FinchTV (accessed on 18 May 2020).

20. GenBank. Available online: https://www.ncbi.nlm.nih.gov/genbank/ (accessed on 18 May 2020).

21. Phytophthora Database. Available online: http://www.phytophthoradb.org/ (accessed on 18 May 2020).

22. La Spada, F.; Stracquadanio, C.; Riolo, M.; Pane, A.; Cacciola, S.O. Trichoderma counteracts the challenge of Phytophthora nicotianae infections on tomato by modulating plant defense mechanisms and the expression of crinkler, necrosis-inducing Phytophthora protein 1, and cellulose-binding elicitor lectin pathogenic effectors. Front. Plant Sci. 2020, 11, 1-16.

23. Aloi, F.; Riolo, M.; Parlascino, R.; Pane, A.; Cacciola, S.O. Bot gummosis of lemon (Citrus $\times$ limon) caused by Neofusicoccum parvum. J. Fungi 2021, 7, 294. [CrossRef]

24. Jung, T.; Jung, M.H.; Cacciola, S.O.; Cech, T.; Bakonyi, J.; Seress, D.; Mosca, S.; Schena, L.; Seddaiu, S.; Pane, A.; et al. Multiple new cryptic pathogenic Phytophthora species from Fagaceae forests in Austria, Italy and Portugal. IMA Fungus 2017, 8, 219-244 [CrossRef]

25. Cacciola, S.O.; Pennisi, A.M.; Agosteo, G.E.; Magnano di San Lio, G. First Report of Phytophthora palmivora on Grevillea spp. in Italy. Plant Dis. 2003, 87, 1006. [CrossRef]

26. Cacciola, S.O.; Pane, A.; Faedda, R.; Rizza, C.; Badalà, F.; Magnano di San Lio, G. Bud and root rot of windmill palm (Trachycarpus fortunei) caused by simultaneous infections of Phytophthora palmivora and P. nicotianae in Sicily. Plant Dis. 2011, 95, 769. [CrossRef] [PubMed]

27. Robideau, G.P.; De Cock, A.W.A.M.; Coffey, M.D.; Voglmayr, H.; Brouwer, H.; Bala, K.; Chitty, D.W.; Désaulniers, N.; Eggertson, Q.A.; Gachon, C.M.M.; et al. DNA barcoding of oomycetes with cytochrome c oxidase subunit I and internal transcribed spacer. Mol. Ecol. Resour. 2011, 11, 1002-1011. [CrossRef] [PubMed]

28. Migliorini, D.; Ghelardini, L.; Tondini, E.; Luchi, N.; Santini, A. The potential of symptomless potted plants for carrying invasive soilborne plant pathogens. Divers. Distrib. 2015, 21, 1218-1229. [CrossRef]

29. Van Tri, M.; Van Hoa, N.; Minh Chau, N.; Pane, A.; Faedda, R.; De Patrizio, A.; Schena, L.; Olsson, C.H.B.; Wright, S.A.I.; Ramstedt, M.; et al. Decline of jackfruit (Artocarpus heterophyllus) incited by Phytophthora palmivora in Vietnam. Phytopathol. Mediterr. 2015, $54,275-280$.

30. Redekar, N.R.; Eberhart, J.L.; Parke, J.L. Diversity of Phytophthora, Pythium, and Phytopythium species in recycled irrigation water in a container nursery. Phytobiomes J. 2019, 3, 31-45. [CrossRef]

31. Scanu, B.; Jung, T.; Masigol, H.; Linaldeddu, B.T.; Jung, M.H.; Brandano, A.; Mostowfizadeh-Ghalamfarsa, R.; Janoušek, J.; Riolo, M.; Cacciola, S.O. Phytophthora heterospora sp. nov., a new pseudoconidia-producing sister species of P. palmivora. J. Fungi 2021, 7, 870. [CrossRef]

32. Graham, J.H.; Bright, D.B.; McCoy, C.W. Phytophthora-Diaprepes weevil complex: Phytophthora spp. relationship with citrus rootstocks. Plant Dis. 2003, 87, 85-90. [CrossRef]

33. Lo Giudice, V.; Raudino, F.; Magnano di San Lio, R.; Cacciola, S.O.; Faedda, R.; Pane, A. First report of a decline and wilt of young olive trees caused by simultaneous infections of Verticillium dahliae and Phytophthora palmivora in Sicily. Plant Dis. 2010, $94,1372$. [CrossRef]

34. Pane, A.; Cacciola, S.O.; Scibetta, S.; Bentivenga, G.; Magnano di San Lio, G. Four Phytophthora species causing foot and root rot of apricot in Italy. Plant Dis. 2009, 93, 844. [CrossRef]

35. Pane, A.; Faedda, R.; Cacciola, S.O.; Rizza, C.; Scibetta, S.; Magnano di San Lio, G. Root and basal stem rot of mandevillas caused by Phytophthora spp. in Eastern Sicily. Plant Dis. 2010, 94, 1374. [CrossRef] 
36. Puglisi, I.; De Patrizio, A.; Schena, L.; Jung, T.; Evoli, M.; Pane, A.; Van Hoa, N.; Van Tri, M.; Wright, S.; Ramstedt, M.; et al. Two previously unknown Phytophthora species associated with brown rot of Pomelo (Citrus grandis) fruits in Vietnam. PLoS ONE 2017, 12, e0172085. [CrossRef] [PubMed]

37. Aloi, F.; Zamora-Ballesteros, C.; Martín-García, J.; Diez, J.J.; Cacciola, S.O. Co-Infections by Fusarium circinatum and Phytophthora spp. on Pinus radiata: Complex Phenotypic and Molecular Interactions. Plants 2021, 10, 1976. [CrossRef]

38. Elvira-Recuenco, M.; Cacciola, S.O.; Sanz-Ros, A.V.; Garbelotto, M.; Aguayo, J.; Solla, A.; Mullett, M.; Drenkhan, T.; Oskay, F.; Aday Kaya, A.G.; et al. Potential interactions between invasive Fusarium circinatum and other pine pathogens in Europe. Forests 2020, 11, 7. [CrossRef]

39. Drenth, A.; Guest, D. Phytophthora palmivora in tropical tree crops. In Phytophthora a Global Perspective; Lamour, K., Ed.; CABI: Oxfordshire, UK, 2013; pp. 187-196.

40. Kamoun, S.; Furzer, O.; Jones, J.D.G.; Judelson, H.S.; Ali, G.S.; Dalio, R.J.D.; Roy, S.G.; Schena, L.; Zambounis, A.; Panabières, F.; et al. The top 10 oomycete pathogens in molecular plant pathology. Mol. Plant Pathol. 2015, 16, 413-434. [CrossRef]

41. Biasi, A.; Martin, F.N.; Cacciola, S.O.; Magnano Di San Lio, G.M.; Grünwald, N.J.; Schena, L. Genetic analysis of Phytophthora nicotianae populations from different hosts using microsatellite markers. Phytopathology 2016, 106, 1006-1014. [CrossRef]

42. Derevnina, L.; Petre, B.; Kellner, R.; Dagdas, Y.F.; Sarowar, M.N.; Giannakopoulou, A.; de la Concepcion, J.C.; Chaparro-Garcia, A.; Pennington, H.G.; van West, P.; et al. Emerging oomycete threats to plants and animals. Philos. Trans. R. Soc. Biol. Sci. 2016, 371, 20150459. [CrossRef]

43. Panabières, F.; Ali, G.S.; Allagui, M.B.; Dalio, R.J.D.; Gudmestad, N.C.; Kuhn, M.L.; Guha Roy, S.; Schena, L.; Zampounis, A. Phytophthora nicotianae diseases worldwide: New knowledge of a long-recognised pathogen. Phytopathol. Mediterr. 2016, 55, 20-40.

44. Guo, Y.; Sakalidis, M.L.; Torres-Londoño, G.A.; Hausbeck, M. Population structure of a worldwide Phytophthora palmivora collection suggests lack of host specificity and reduced genetic diversity in South American and Caribbean. Plant Dis. 2021. [CrossRef]

45. Mammella, M.A.; Martin, F.N.; Cacciola, S.O.; Coffey, M.D.; Faedda, R.; Schena, L. Analyses of the population structure in a global collection of Phytophthora nicotianae isolates inferred from mitochondrial and nuclear DNA sequences. Phytopathology 2013, 103, 610-622. [CrossRef] [PubMed]

46. Prigigallo, M.I.; Mosca, S.; Cacciola, S.O.; Cooke, D.E.L.; Schena, L. Molecular analysis of Phytophthora diversity in nursery-grown ornamental and fruit plants. Plant Pathol. 2015, 64, 1308-1319. [CrossRef]

47. Mehrotra, M.D. Diseases of Paulownia and their management. Indian For. 1997, 123, 66-72.

48. Phytophthora Root Rot Plant List. RHS Gardening Advise. September 2020. Available online: https://www.rhs.org.uk/advice/ pdfs / phytophthora-host-list.pdf (accessed on 10 October 2021).

49. Ministry for Primary Industries Standard 155.02.06. Importation of Nursery Stock. Available online: https://www.mpi.govt.nz/ dmsdocument/1152-nursery-stock-import-health-standard (accessed on 10 October 2021).

50. Quarantine Pests (Fungi) Declined Entry into Sudan = (Zero Tolerance). Available online: https://assets.ippc.int $/ \mathrm{static} / \mathrm{media} /$ files/reportingobligation/2016/09/25/Quarantined_and_non-Quarantined_pest_list_in_Sudan.pdf (accessed on 10 October 2021).

51. Abad, Z.G.; Abad, J.A.; Cacciola, S.O.; Pane, A.; Faedda, R.; Moralejo, E.; Pérez-Sierra, A.; Abad-Campos, P.; Alva-rez-Bernaola, L.A.; Bakonyi, J.; et al. Phytophthora niederhauserii sp. nov., a polyphagous species associated with ornamentals, fruit trees and native plants in 13 countries. Mycologia 2014, 106, 431-447. [CrossRef] [PubMed]

52. Jung, T.; Orlikowski, L.; Henricot, B.; Abad-Campos, P.; Aday, A.G.; Aguín Casal, O.; Bakonyi, J.; Cacciola, S.O.; Cech, T.; Chavarriaga, D.; et al. Widespread Phytophthora infestations in European nurseries put forest, semi-natural and horticultural ecosystems at high risk of Phytophthora diseases. For. Pathol. 2016, 46, 134-163. [CrossRef]

53. Garbelotto, M.; Frankel, S.J.; Scanu, B. Soil- and waterborne Phytophthora species linked to recent outbreaks in Northern California restoration sites. Calif. Agric. 2018, 72, 208-216. [CrossRef]

54. Simamora, A.V.; Paap, T.; Howard, K.; Stukely, M.J.C.; Hardy, G.E.S.J.; Burgess, T.I. Phytophthora contamination in a nursery and its potential dispersal into the natural environment. Plant Dis. 2018, 102, 132-139. [CrossRef]

55. Sims, L.; Tjosvold, S.; Chambers, D.; Garbelotto, M. Control of Phytophthora species in plant stock for habitat restoration through best management practices. Plant Pathol. 2019, 68, 196-204. [CrossRef]

56. Sims, L.L.; Chee, C.; Bourret, T.; Hunter, S.; Garbelotto, M. Genetic and phenotypic variation of Phytophthora crassamura isolates from California nurseries and restoration sites. Fungal Biol. 2019, 123, 159-169. [CrossRef]

57. Hong, C.X.; Gallegly, M.E.; Richardson, P.A.; Kong, P.; Moorman, G.V.; Lea-Cox, J.D.; Ross, D.S. Phytophthora hydropathica, a new pathogen identified from irrigation water, Rodhodendron catawbiense and Kalmia latifolia. Plant Pathol. 2010, 19, 913-921. [CrossRef]

58. Loyd, A.; Benson, D.M.; Ivors, K.L. Phytophthora populations in nursery irrigation water in relationships to pathogenicity and infection frequency of rhododendron and pieris. Plant Dis. 2014, 98, 1213-1220. [CrossRef] 